\title{
Oktatás koronavírus idején. Tanárszakos hallgatók véleménye a távolléti oktatás időszakáról
}

\section{Buda András}

\author{
Debreceni Egyetem, Bölcsészettudományi Kar habilitált adjunktusa \\ buda.andras@arts.unideb.hu
}

\begin{abstract}
A koronavírus megjelenése alapjaiban változtatta meg az oktatás permanens digitalizálódásának folyamatát. A közoktatásban dolgozóknak egyik pillanatról a másikra kellett átállni a távolléti oktatásra, de a felsőoktatási intézményeknek is csak néhány napjuk volt az új tartalmak, módszerek kidolgozására. Vizsgálatunkban a távolléti oktatás befejezésekor a Debreceni Egyetem tanárszakos hallgatóinak véleményét, tapasztalatait gyüjtöttük össze online elérhetô, általunk összeállitott kérdőivünk segítségével. Kérdéseinkre 144-en válaszoltak. A tanulmányban az eredmények ismertetésével be kívánjuk mutatni, hogy a hallgatók véleménye alapján mennyire volt sikeres az átállás, melyek voltak az új oktatási forma legjellemzőbb problémái, és melyek azok az elemek, melyek átemelésével a jelenléti oktatás is jobbá tehetó.
\end{abstract}

Kulcsszavak: IKT, COVID-19, tanárszakos hallgatók, tapasztalatok, távolléti oktatás

DOI: 10.37205/TEL-hun.2020.1-2.04

\section{Bevezetés}

Bár a digitális technológia folyamatosan megújuló termékei, megoldásai számos problémát indukálnak, és gyakran váltanak ki vitákat (Goldin \& Katz, 2008), nevelési, oktatási folyamatban történő szükségszerű megjelenésüket ma már szinte senki nem kérdőjelezi meg (Piccianon, 2019).

A 21. századi környezetben nevelkedő fiatalok számára az IKT és az internet egyértelműen része az oktatási rendszernek is, melynek legmagasabb szintje, a felsőoktatás már el sem képzelhető digitális technológia nélkül (Nichols, 2020). Sőt, Magyarországon már a bekerüléshez is szükség van a technológia használatára, a felsőoktatásba történő jelentkezés ugyanis kizárólag online történhet. A képzésekre beiratkozó hallgatók pedig csak valamilyen tanulmányi rendszeren (például Neptun, ETR) keresztül intézhetik hivatalos teendőiket. Ezen túlmenően a felsőoktatási intézményekbe járók a tanítási-tanulási folyamat során is jó néhány 
olyan megoldással találkoznak, mely a technológia adta lehetőségek kihasználásán alapul.

\section{IKT a felsőoktatásban}

Teljesen természetes, hogy napjaink felsőoktatásában az oktatók digitális prezentációt alkalmaznak, ma már inkább ennek a hiánya számít szokatlannak. Az is teljesen megszokottá vált, hogy az oktatók szövegszerkesztővel kérik elkészíteni a hallgatói dolgozatokat, beadandókat, napjainkban már csak néhány helyen fogadnak el kézírással készült munkát. Ezzel párhuzamosan pedig egyre többen vannak azok is, akiknek a beadandókat nem papír alapon, hanem digitálisan kell leadni.

Ezek a változások tagadhatatlanul a digitalizálódás irányába mutatnak, de valójában alig módosítják a korábbi gyakorlatot, mivel az IKT használat csak a pedagógus munkáját könnyíti meg, módszertani megújulás csak ritkán társul hozzá. Ugyanakkor viszont nagyon könnyü ezen a szinten megrekedni! Egyrészt elégedetté teheti az érintettet az, hogy az órái látványosan megváltoznak, másrészt a fenti módosításokkal tanúbizonyságot tesz arról, hogy használja az új technológiát, ő tehát ezt a „feladatot” is elvégezte. Közben viszont - a változás ellenére - a hallgatói ugyanúgy élik meg az órákat (passzívan, nem feltétlenül gondolkodva), mint korábban, csak most digitális támogatás mellett.

Valódi átalakulásról csak akkor beszélhetünk, amikor a látványos, de csak látszólagos változások helyett újfajta tevékenységek, kreatív, alkotó feladatok megtervezése, előkészítése válik elsődleges fontosságúvá a pedagógus számára. Így érhető el, hogy a passzív tudásfogyasztó tanulókra kialakított tanárközpontú oktatás (tanulás 1.0) közösségi, kollaboratív munkára épülő tanulóközpontú tanulási folyamattá (tanulás 2.0) alakuljon át. A technológiának tehát lehetővé kell tennie, hogy a hallgatók - tudásépítés révén - a folyamat aktív részeseivé váljanak, beadandó dolgozat helyett például valamilyen multimédia alapú produktumot kelljen készíteniük, a prezentáció pedig valamilyen kollaborációs felület alkalmazásával - lehetőleg animációkat, videókat tartalmazva - ne egyéni, hanem csapatmunkával szülessen meg.

$\mathrm{Az}$ internet rohamos fejlődésével az informális oktatás szerepe is egyre fontosabbá válik, a felhasználók ugyanis szinte korlátlanul juthatnak hozzá az őket érdeklő információkhoz. „Ez a személyre szabott tartalom kulcsfontosságú és nagy különbséget jelent a hagyományos oktatási rendszerek ömlesztett tananyagaihoz képest.” (Kismihók, 2011, p. 2). A hallgatók az igényeiknek megfelelő specifikus 
információkhoz a mesterséges intelligenciával támogatott mobiltechnológiák révén bárhol, bármikor hozzájuthatnak, így a korábban szinte kizárólag iskolákhoz kapcsolódó tudáselsajátítás napjainkra már mindenütt jelenlévő tanulássá (tanulás 3.0) alakult át (Turcsányi-Szabó, 2011).

Amennyiben oktatóként tudatosan építünk az idő- és helyfüggetlen tanulásra, akkor olyan lehetőségeket is kiaknázhatunk, melyekre korábban egyáltalán nem volt mód. A digitális technológia segítségével például hatalmas mennyiségű adatot gyưjthetünk a diákok tanórai, illetve tanórán kívüli tanulási tevékenységeiről (Martin \& Sherin, 2013). Monitorozni lehet a teljes tanulási folyamatot, hiszen az oktatási keretrendszerek rögzítik a diákok összes interakcióját, melyet a tananyaggal kapcsolatban valósítanak meg. Számontartanak minden egyes egérkattintást, az egyes tevékenységek (például az olvasás, a feladatmegoldás) időadatait, a teszt kitöltési próbálkozások számát, a tipikus hibákat stb. „A tanulási analitika segítségével nemcsak azt lehet ellenőrizni, hogy a megadott egységet elsajátították-e a tanulók, hanem real time figyelni lehet, hogy a kijelölt tanulási tevékenységet végzik-e. Azonosítani lehet azon csoportokat, amelyeknek további segítségre van szükségük; adaptív (számítógép által vezérelt), illetve adaptálható (ember által irányított) technikákat alkalmazva még hatékonyabban lehet illeszteni a tanulók igényeihez az oktatás egészét” (Molnár et al., 2020, pp. 62-63). Az adatbázisok megfelelő elemzésekkel mindezeken túl hozzájárulhatnak a tanulást támogató rendszerek továbbfejlesztéséhez, illetve új elméletek, módszerek kidolgozásához is. Éppen ezért állítják Johnson és munkatársai (2016), hogy a tanulási analitika a 21. század egyik legjelentősebb fejlesztése.

Mivel az „elmúlt tíz évben közel hétszeresére nőtt a kézben tartható technológiák használata” (Molnár et al., 2020, p. 59), a hallgatók oldaláról jelentősen megnőtt az igény az oktatási tartalmak interneten történő elérése iránt. Ennek ellenére nem történt jelentős mértékű változás, a teljesen digitális alapokon nyugvó oktatás ugyanis nem igazán szorítható be a hagyományos rendszerek keretei közé. Éppen ezért a magyar felsőoktatási intézményekben alig van példa e-learning alapú képzésekre, vagy legalább e-learning megoldások beépítésére az oktatási folyamatba. Annak ellenére ugyanis, hogy valamilyen e-learning keretrendszer általában elérhető az intézményekben, azok leginkább egyfajta „tananyagraktár” funkciót (Erdős \& Koloszár, 2016) töltenek be, ahol az oktatók pusztán a hagyományos tananyagok (jegyzetek, diasorok, órai segédletek) hozzáférését biztosítják a hallgatók számára. A felsőfokú képzés alatt szerzett oktatási célú IKT alkalmazással 
kapcsolatos tapasztalatok éppen ezért nagyon korlátozottak, ami különösen a leendő tanárok esetén jelent problémát, mivel a pedagógusok, reflektálás hiányában, alapvetően úgy tanítanak, ahogyan annak idején őket tanították, és nem az alapján, amit a képzés során tanítottak nekik (Falus, 2001).

A felsőfokú tanulmányok alatt szerzett IKT tapasztalat, illetve inkább annak hiánya, meghatározó a későbbi munkavégzés során megvalósuló saját IKT használat szempontjából is (Admiraal et al., 2017). ${ }^{1}$ Számos kutatás bizonyította (például Aslan \& Zhu, 2016; Dringó-Horváth \& Gonda, 2018), hogy az egyetemi évek alatt a hallgatók leginkább az IKT-eszközök tanárközpontú alkalmazásával találkoznak, az oktatók technológia használata elsősorban szemléltetési céllal történik, ritkán valósul meg a tanulók aktivizálása, kollaborációja. Ennek megfelelően a frissen végzettek leggyakrabban „prezentációs céllal használják az IKT-t, vagy a tudás és készségek gyakorlására, ugyanakkor kevésbé jellemző, hogy a kezdő tanárok arra használnák az IKT-eszközöket, hogy azok facilitálják a diákok közötti együttmüködést, a kreativitást vagy a kritikai gondolkodást." (Lanszki \& Faragó, 2020, p. 32). A képzés és a gyakorlat éveinek meghatározó kölcsönhatása miatt (Ottenbreit-Leftwich, et al., 2018) Tondeur és kutatótársai azt javasolják, hogy a leendő tanárok képzése során az IKT használatra történő felkészítés ne külön kurzusok keretein belül valósuljon meg, hanem a szakmai tartalom lehetőleg minden tárgy esetén kapcsolódjon össze a megfelelő pedagógiai és technológiai tudással (Tondeur et al., 2016), hogy minél több mintát lássanak és tapasztaljanak meg a tanárjelöltek. Ezzel szemben napjaink gyakorlata nem ebbe az irányba mutat, legtöbbször csak néhány pedagógiai és/vagy tantárgypedagógiai kurzus keretein belül történik meg a célzott felkészítés az IKT oktatási alkalmazására, a többi tárgy esetén csak nagyon kis lépésekben, lassan valósul meg a digitalizálódás (DringóHorváth, 2018).

\section{Kutatás a Debreceni Egyetemen}

A 2020 tavaszán kirobbant koronavírus járvány miatt a felsőoktatásban oktatóknak pillanatok alatt kellett átállni a távolléti oktatásra. A tantárgy típusától függetlenül néhány nap alatt kellett kidolgozni az új képzési formának megfelelő digitális tartalmakat, módszereket. Ennek az időszaknak a tanulságai különböző szempontokból vizsgálhatók. Kutatásunkban a Debreceni Egyetem tanárszakos

\footnotetext{
${ }^{1}$ A pályakezdés éveit a korábban tanultak és tapasztaltak mellett jelentősen befolyásolja például az iskola infrastrukturális ellátottsága, illetve az igazgató attitűdje, támogatása is (Starkey, 2010).
} 
hallgatóinak véleményét gyüjtöttük össze nyitott és zárt kérdéseket is tartalmazó, online elérhető (Google Forms), általunk összeállított kérdőív segítségével.

Feltáró jellegű kutatásunk alapvetően a tapasztalatok összegyüjtését célozta, a 2020-as tavaszi félév távolléti oktatásának legjellemzőbb jegyeit igyekeztünk feltárni. Azt vizsgáltuk, hogyan élték meg a távolléti oktatás első szakaszát a leendő pedagógusok. Kiemelt figyelmet fordítottunk a problémák megismerésére, hogy az esetlegesen megvalósuló (és közben valóban bekövetkező) hasonló helyzetre felkészültebben reagálhassanak az érintettek. A válaszadásra a távolléti oktatás első időszakának befejezésekor, 2020. június elején került sor. Azokat kértük kérdőívünk kitöltésére, akik már elkezdték pedagógiai-pszichológiai tanulmányaikat, azaz legalább a negyedik félévüket töltötték tanárszakon tavasszal az egyetemen. A kérést és az önkéntes, anonim kérdőív linkjét az egyetemi vezetés engedélyének birtokában a Neptun tanulmányi rendszeren keresztül juttattuk el a hallgatókhoz. A válaszadásra vonatkozó kérésünket a szakirodalmi javaslatoknak (például Nulty, 2008; Mol, 2017) megfelelően még két alkalommal ismételtük meg. Végül a 803 potenciális válaszadótól - adattisztítás után - 144 értékelhető adatsorhoz jutottunk, ez 18\%-os kitöltési arányt jelent. Ez az érték alacsonyabb, mint az online kérdőívek estén egyes szerzők (például Nulty, 2008; Lindemann, 2019) szerinti átlagosnak tekinthető (30\%-os) kitöltési arány, ugyanakkor viszont megfelel a már évek óta tartó, de a járvány miatt felerősödő tendenciának: az internetes kérdőíves adatgyüjtés egyre csökkenő válaszadási arányt eredményez (Veresné, 2010; Beullens et al., 2018). Különösen igaz ez a megállapítás a felsőoktatásban részt vevő hallgatókra (Avery et al., 2006; Adams \& Umbach, 2012), akik a társadalom legtöbbet vizsgált népességcsoportjai közé tartoznak (Sax et al., 2003), és nagyon sokszor kapnak kérdőív kitöltésére irányuló kérést. Mol (2017) mért olyan kiugró eredményeket, amikor három hónap alatt átlagosan 1,5 naponként érkezett ilyen kérés az antwerpeni egyetem hallgatóihoz. Ez a hatalmas mennyiség természetesen jelentősen csökkenti a kitöltési hajlandóságot. Ugyanakkor a válaszhiány nem feltétlenül tudatos elzárkózást jelez, a hallgatók ugyanis nem mindig használják a tanulmányi rendszerben megadott e-mail-címüket, illetve nemegyszer figyelmen kívül hagyják a rendszerben érkező, nem egyértelműen valamilyen kurzushoz vagy hivatalos teendőhöz kapcsolódó leveleket (Mol, 2017).

A kérdőívünket kitöltő 97 női és 47 férfi válaszadó az egyetem négy különböző karának hallgatója. Megoszlásuk nem tekinthető reprezentatívnak, mert az Informatika Kar hallgatói teljes létszámukhoz (16 fó) képest felülreprezentáltak, míg a 
Zenemüvészeti Kar hallgatói (82 fő) jelentősen alulreprenzentáltak, ami összefügghet azzal, hogy a digitális technológia alkalmazása az ő szakterületüktől áll legtávolabb (1. ábra).

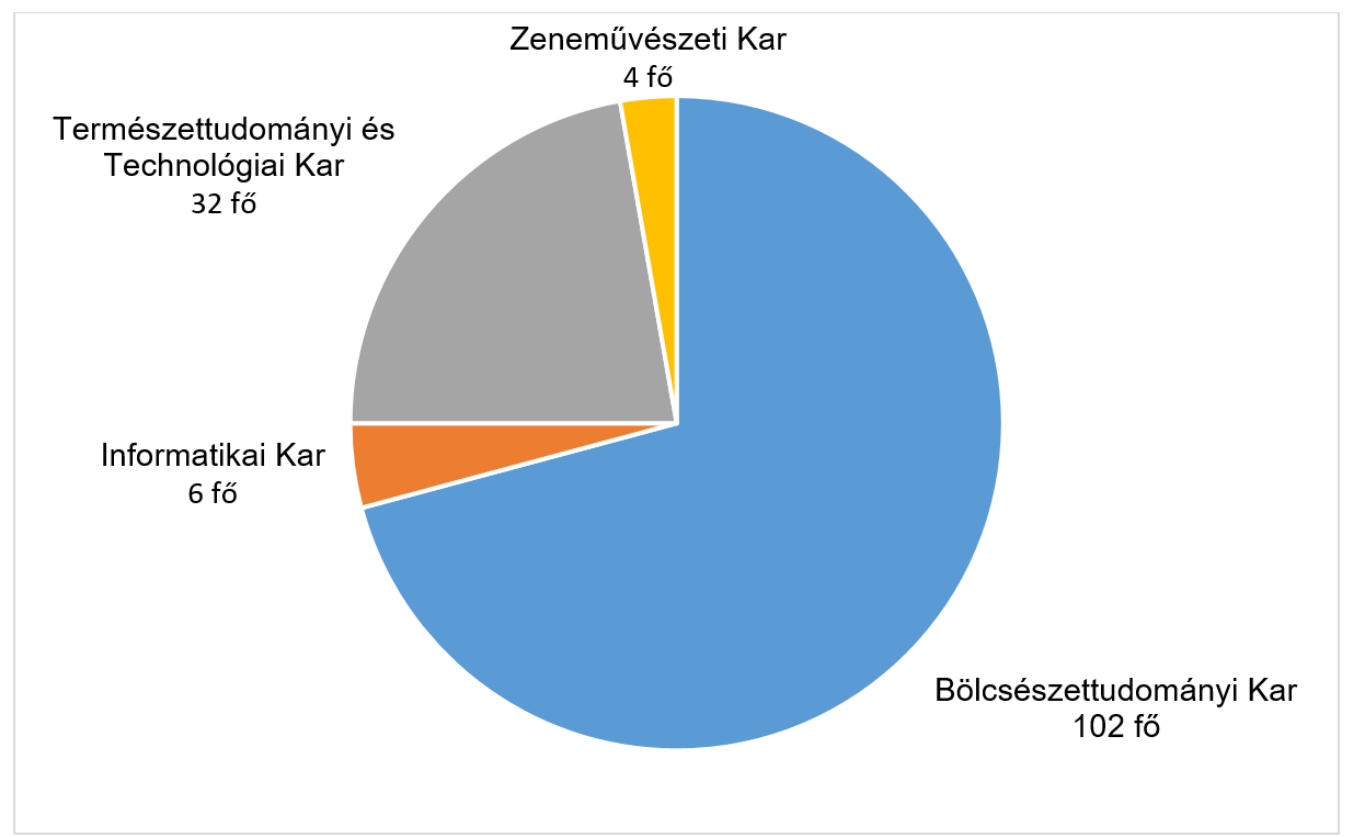

1. ábra: A válaszadók megoszlása karok szerint.

Az általunk feltett kérdések három csoportra bonthatók. Vizsgáltuk (1) a kiindulási feltételeket, (2) a távolléti oktatás gyakorlatának néhány elemét, illetve (3) a félév során tapasztaltak utólagos megítélését. Ezek előtt arra kértük a hallgatókat, hogy írjanak három jelzőt, mely a távolléti oktatással kapcsolatban először eszükbe jut. Így kívántuk azt biztosítani, hogy a kérdőív további kérdései egyáltalán ne befolyásolják a válaszadókat. ${ }^{2}$ A távolléti oktatás jellemzésére vonatkozó válaszokat kódoltuk, és három csoportba soroltuk. Heten nem válaszoltak a kérdésre, egy hallgató két jelzőt írt, hárman pedig csak egyetlen elemet fogalmaztak meg. Nem várt módon a távolléti oktatással kapcsolatban alapvetően a „stressz”, ${ }^{3}$ a „nehézségek”, a „nagyobb elvárások” kifejezések jutottak a kérdezettek eszébe, és az említések között csak elvétve fordult elő pozitív (például „rugalmas”, „kényelmes”) vagy nem negatív (például „változó”, „kezelhető”) jelző. A 133 hallgató

\footnotetext{
${ }^{2}$ Ezt erősítendő jelen vizsgálatban nem kértük a hallgatókat arra, hogy külön adjanak választ a pedagógiai-pszichológia kurzusok, illetve a két diszciplináris terület tárgyainak vonatkozásában.

${ }^{3} \mathrm{~A}$ stressz több kutatásban is a legjellemzőbb jegyek között szerepel (lásd például Espino-Díaz et al., 2020; Kasza, 2020; Petillion \& McNeil, 2020; Srivastav et al., 2021).
} 
közül csak hatan írtak három egyértelműen pozitív jelentésű szót, és az összesen 404 válaszelemből csak 78 (19\%) volt nem negatív.

\section{Kiindulási feltételek}

A válaszokból hamar kiderült, hogy a negatív vélemények alapvetően nem a kiindulási feltételek miatt alakultak ki. A válaszok alapján ugyanis a hallgatók 90\%ának már március közepén rendelkezésére állt a legfontosabb feltétel, a megfelelő sávszélességű internet elérés, $10 \%$-uknak viszont nagyobb sebességet vagy adatforgalmat lehetővé tevő szolgáltatást kellett vásárolnia. A két arány viszont egyben azt is mutatja, hogy olyan nem volt közöttük, aki a távolléti oktatás kezdetekor ne rendelkezett volna valamilyen minőségü internet eléréssel.

A hallgatók technikai eszközökkel is el voltak látva: 21 fő (14,6\%) használt ezek közül csak egyet, mindenki más legalább kettő-három, öt fő viszont négy eszközt is használt egyetemi feladatai teljesítéséhez a távolléti oktatás ideje alatt (1. táblázat).

\begin{tabular}{lcc}
\hline \multirow{2}{*}{ Eszköz } & \multicolumn{2}{c}{ A használók } \\
\cline { 2 - 3 } & Száma & Aránya \\
\hline asztali számítógép & 38 & $26,4 \%$ \\
laptop & 140 & $97,2 \%$ \\
mobiltelefon & 119 & $82,6 \%$ \\
tablet & 21 & $14,6 \%$ \\
\hline 1. táblázat: A válaszadók által használt eszközök megoszlása (n=144).
\end{tabular}

A válaszadók közül majdnem mindenki használt laptopot, és a mobiltelefonok alkalmazása is nagyon gyakori volt a kérdezettek között. Különösen az utóbbi eredmény figyelemre méltó, erre tekintettel kell majd lenni a jövőben a digitális tartalmak tervezésekor. A kisebb képernyő miatt ugyanis kiemelten kell majd figyelni a megfelelő méret, szín, elrendezés használatára vagy a reszponzív megjelenítés ${ }^{4}$ alkalmazására.

\footnotetext{
${ }^{4}$ A reszponzív megjelenítés azt jelenti, hogy a tartalom automatikusan igazodik a látogató képernyojének felbontásához, függetlenül attól, hogy milyen eszközről (mobilról, tabletről vagy laptopról) kerül sor az oldal megtekintésére.
} 
A rendelkezésre álló eszközök, illetve az internet elérés azonban csak a szükséges feltételeket jelentik a távolléti oktatáshoz, a tanítási-tanulási folyamat megvalósulásához tudni is kell használni ezeket az eszközöket, illetve a szükséges programokat.

A távolléti oktatás kezdetekor saját digitális felkészültségüket a hallgatók meglehetősen jónak minősítették, a 10 fokú Likert-skálán (1 = digitális analfabéta, ..., 10 = digitális profi) csak heten (öt férfi és két nő) adtak maguknak hatosnál kisebb értéket, míg oktatóik tudásának megítélésekor 71 esetben jártak el így (2. ábra). Összességében a saját tudásszintet átlagosan 7,8-ra, az oktatóit pedig csak 5,4-re értékelték a kérdőívet kitöltő tanárjelöltek.

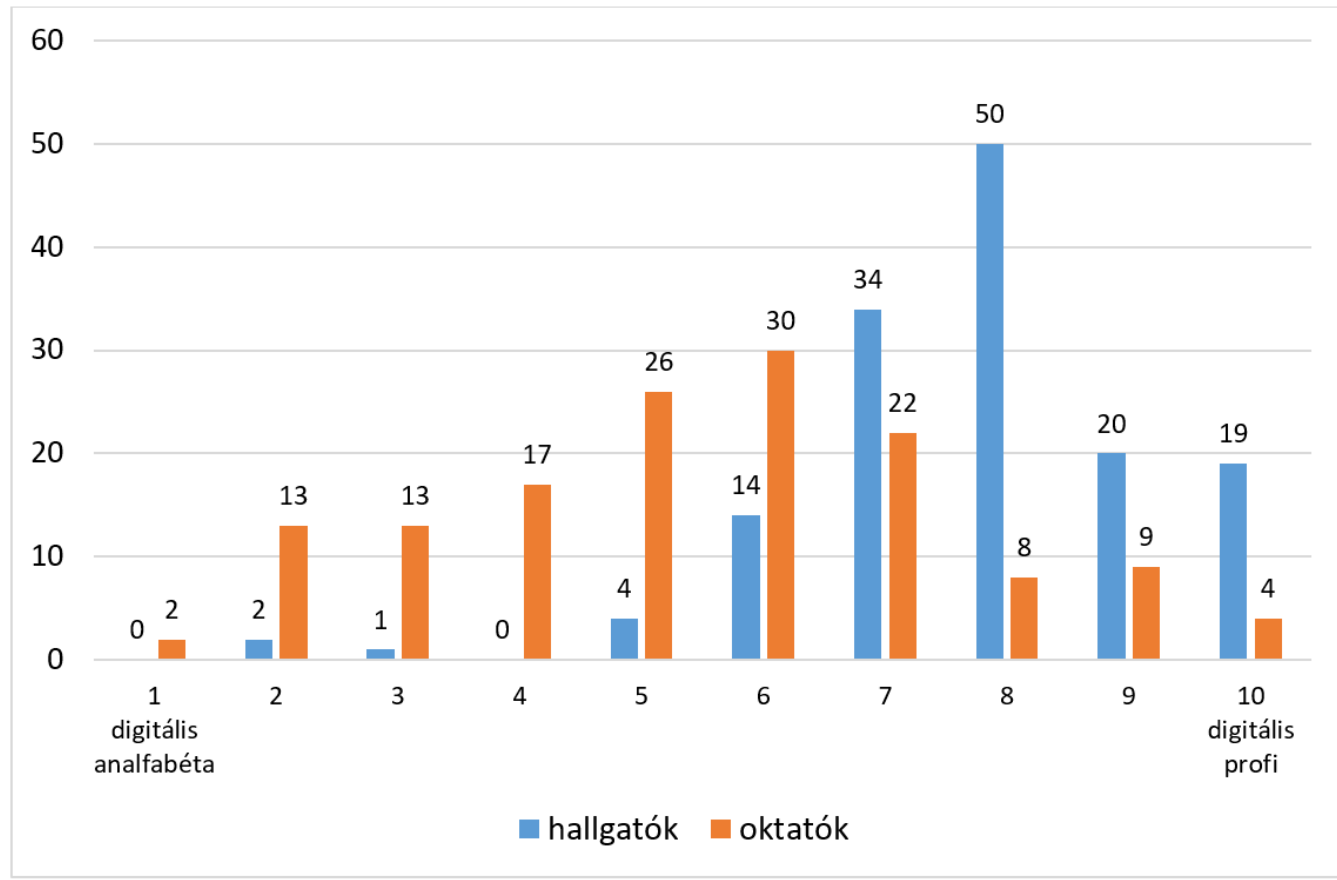

2. ábra: A digitális felkészültség megítélése a távolléti oktatás kezdetekor (fö) (n=144).

\section{A távolléti oktatás gyakorlata}

A távolléti oktatás kivitelezése alapvetően kétfajta módon történt. Az egyik a szinkron megvalósuló online óratartás, ehhez különböző platformok közül lehetett választani. A másik forma, az aszinkron megoldás során pedig az oktatók különböző típusú tananyagokat (például jegyzeteket, diasorokat, videókat) tettek a hallgatók számára elérhetővé, akik ezekre támaszkodva, saját tempójukban, egyé- 
ni időbeosztás szerint sajátították el az ismereteket, mely folyamatot az oktatók például konzultációkkal, önellenőrző tesztekkel, beadandókkal segítették és kontrollálták. A tananyagok megosztásához leggyakrabban használt felületeket a 2 . táblázat tartalmazza.

\begin{tabular}{lcc}
\hline & \multicolumn{2}{c}{ Az említések } \\
\cline { 2 - 3 } & Száma & Aránya \\
\hline Facebook & 67 & $46,5 \%$ \\
Google Classroom & 105 & $72,9 \%$ \\
Google Drive & 97 & $67,4 \%$ \\
Moodle & 110 & $76,4 \%$ \\
OneDrive & 13 & $9,0 \%$ \\
\hline 2. táblázat: A tananyagok megosztásához használt felületek típusa $(\mathrm{n}=144)$.
\end{tabular}

A Moodle jelentős szerepe minden bizonnyal annak köszönhető, hogy a tanárképzésben (elsősorban a pedagógiai tárgyakat) oktatók közül sokan már korábban is alkalmazták ezt a felületet, gyakran osztottak meg itt kiegészítő anyagokat, információkat vagy éppen a beadandó feladatokat kérték ide feltölteni. Éppen ezért több oktató választotta azt a megoldást, hogy ezt a fajta munkát kiszélesítik, kibővítik, és aszinkron módon a Moodle-ban szervezik meg a tantárgy oktatását a távolléti oktatás idejére. Összességében azonban még többen voltak azok, akik valamelyik Google szolgáltatást használták ebből a célból. A Google Drive-ot már korábban is sokan kipróbálták (igaz, elsősorban magán célra), Google Classroomot pedig kimondottan oktatási célból kezdték el sokan alkalmazni.

A szinkron és aszinkron megoldások közül az utóbbiak voltak gyakoribbak, a hallgatók által félév elején felvett átlagosan 14 tantárgyból 9 oktatása zajlott ilyen módon. Azaz a válaszadóknak átlagosan hetente öt tantárgyhoz kapcsolódóan volt online előadásuk vagy gyakorlatuk, ez valamivel több mint harmada a teljesítendő kurzusok számának. A hallgatók terheltsége között meglehetősen nagy különbség volt, hárman csak hat tárgyat vettek fel a tavaszi félévben, 13-an viszont legalább 20 tárgy teljesítését tervezték be. Az online órák szempontjából még nagyobbak voltak az eltérések. Voltak olyan tanárjelöltek (hatan is), akiknek minden 
tantárgyát megtartották online, de akadt olyan hallgató is, akinek egyetlen tantárgyához sem tartozott interneten lebonyolított szinkron óra.

Akár az egyéni felkészülést, akár az online órákat tekintjük, az egyetemi feladatok teljesítése elég időigényesnek bizonyult a távolléti oktatás időszakában. A válaszadók hétköznap átlagosan 6,6 órát töltöttek ilyen feladatok teljesítésével, és hétvégén is csak kis mértékben csökkent ez az érték (6 órára). Ennél a kérdésnél is születtek szélsőséges válaszok: az egy órás elfoglaltságtól a 15 órás (ez volt a maximálisan megjelölhető érték) terhelésig mindenféle válasz bejelölésre került. A válaszadók valamivel több mint harmada ( 57 fó) hétköznap fordított több időt az egyetemi feladatokra, közel harmada (43 fö) viszont pontosan fordítva, hétvégén töltött ezzel több időt. A többiek (44 fó) egyenletesen, a hét minden napján azonos terhelést, átlagosan 7 órás elfoglaltságot vállalva teljesítették a feladatokat. Ezek az értékek összességében azt eredményezték, hogy a hallgatók nagyon leterheltnek érezték magukat a távolléti oktatás ide alatt (3. ábra). Csak 13 fó érzékelt némileg csökkenő terhelést a korábbi (jelenléti oktatás) helyzethez képest, közöttük voltak öten (a hatból), akik három pozitív jelzőt írtak a távolléti oktatás jellemzésére irányuló nyitott kérdésünkre.

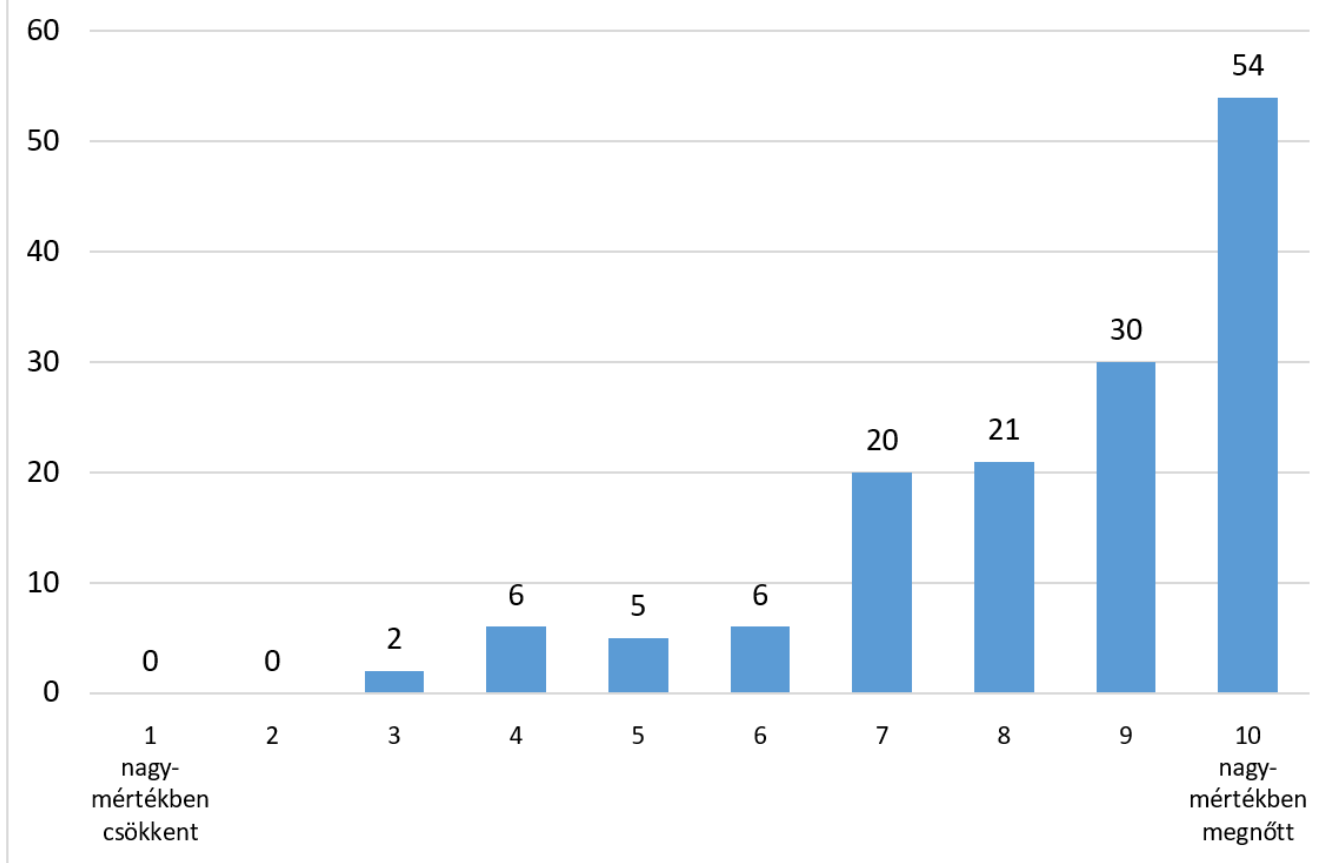

3. ábra: A hallgatói terhelés változásának megítélése a távolléti oktatás ideje alatt (fö) (n=144). 
Érdemes lenne célzottan megvizsgálni azt, minek köszönhető a jelentős többletterhelés érzet, a követelmények ugyanis nem változtak meg ilyen mértékben a távolléti oktatásra történő átállás miatt. A hallgatók véleménye alapján az oktatók közel fele (42\%) egyáltalán nem változtatott az adott tantárgyhoz kapcsolódó feladatokon, 26\%-uk pedig kimondottan enyhített a követelményeken, és csak 32\%kal kapcsolatban állították azt a válaszadók, hogy az online átállás miatt többet kellett teljesíteniük. (A követelmények más intézményekben is változtak, de az eltérések mértéke különböző volt, lásd például: Gonzalez et al., 2020; Kasza, 2020; Serfőző et al., 2020.)

A szinkron tanórák nyilvánvalóan nem növelték a terheket, hanem (az utazási idő megtakarításával) éppen hogy csökkentették azokat. Az online órák megtartásához különböző platformok közül választhattak az oktatók (3. táblázat). Ezek közül kérdőívünkben kilencet soroltunk fel, és bár ezen túlmenően a válaszadók még négy másik megoldást is megneveztek, azokat csak ketten-hárman említették.

\begin{tabular}{|c|c|c|}
\hline \multirow{2}{*}{ Platform } & \multicolumn{2}{|c|}{ Az említések } \\
\hline & Száma & Aránya \\
\hline Discord & 85 & $59,0 \%$ \\
\hline Facebook & 54 & $37,5 \%$ \\
\hline Google Meet & 19 & $13,2 \%$ \\
\hline Hangouts & 17 & $11,8 \%$ \\
\hline Microsoft Teams & 17 & $11,8 \%$ \\
\hline $\begin{array}{l}\text { Moodle webinárium } \\
\text { (BigBlueButton) }\end{array}$ & 115 & $79,9 \%$ \\
\hline Skype & 61 & $42,4 \%$ \\
\hline Webex & 60 & $41,7 \%$ \\
\hline Zoom & 104 & $72,2 \%$ \\
\hline
\end{tabular}

Három olyan platformot találtunk, melyet a válaszadók több mint fele használt, legtöbben Moodle webináriumon (BigBlueButton) vettek részt. A kimagasló 
érték minden bizonnyal annak köszönhető, hogy a tanárképzés részére külön Moodle szerver működik az egyetemen. Ezt egyrészt - ahogy már említettük korábban is sok oktató alkalmazta, így a felület ismerős volt, és ez segítette a kibővített használatot, másrészt a szerver - a megnövekedett terhelés ellenére megbízhatóbban müködött, mint több más megoldás, és alkalmazásának nem volt időkorlátja sem, mint például kezdetben a Zoom-nak, melyet szintén nagyon sokan használtak az oktatók közül. A platformoknál olvasható számértékek ugyanakkor burkoltan jelzik azt a problémát, hogy a hallgatóknak legalább két-három, szélsőséges esetekben viszont akár hat-hét különböző felületet is meg kellett ismerniük. ${ }^{5}$ Ráadásul nem csak használni kellett tudni azokat, hanem azt is számon kellett tartani, hogy melyik tárgy órái melyik felületen kerülnek megtartásra, ügyelve ezen túlmenően arra is, hogy néhány oktató félév közben váltott platformot. A módosításnak három kiváltó oka lehetett: (1) Hallgatói kérés - az általuk javasolt felületet a hallgatók jobban ismerték, vagy szerették, (2) új szolgáltatásra való igény - olyan lehetőségeket akart az oktató felhasználni, melyet az elsőként kiválasztott platform nem tudott biztosítani, (3) technikai problémák.

A hallgatók megítélése szerint átlagosan az online előadások, webináriumok 30 százalékán fordult elő technikai vagy sávszélességből adódó gond, 21-en viszont úgy nyilatkoztak, hogy ez az arány 70-90 százalékos volt. Ezek a magas értékek nem csak rendkívül zavaróak, hanem gyakorlatilag lehetetlenné teszik a munkavégzést, a kommunikációt, így a valódi részvételt a tanórákon. Az ilyen tapasztalatok akár önmagukban is indukálhatnak negatív érzéseket az online tanítássaltanulással kapcsolatban, azonban a technikai vagy sávszélességből adódó gondokon túl még más tényezők is problémát jelenthettek az online előadásokon, webináriumokon, ezek közül a kérdőívben ötöt vizsgáltunk (4. táblázat).

\footnotetext{
${ }^{5}$ Serfőző és társai kutatása (2020) számadatokkal is érzékelteti a probléma jelentőségét: a hallgatók 69\%-a nehéznek érezte a sok oktatási felület menedzselését.
} 
Lehetséges problémák

Az említések

\begin{tabular}{lcc}
\cline { 2 - 3 } & Száma & Aránya \\
\hline a személytelenség & 83 & $61,9 \%$ \\
az oktatók nem ismerték eléggé a használt programot & 73 & $54,5 \%$ \\
a hallgatók nem ismerték eléggé a használt programot & 66 & $49,3 \%$ \\
a tananyag tartalma & 48 & $35,8 \%$ \\
a gyenge minőségű prezentáció & 40 & $29,9 \%$ \\
\hline
\end{tabular}

4. táblázat: $\mathrm{Az}$ online órák lehetséges problémaforrásai $(\mathrm{n}=134)$.

Amint az adatokból látható, elsősorban a személytelenség, a hallgatótársak és az oktatók hiánya jelentett problémát a kérdezetteknek. (Hasonló eredményre jutott Espino-Díaz et al., 2020; Papp-Danka \& Lanszki, 2020; Serfőző et al., 2020.) Hiába ugyanis az audio- és a videókapcsolat, a kommunikáció, az interakciók intenzitása, mélysége jelenleg még nem tudja megközelítőleg sem visszaadni a személyes találkozások érzetét, különösen csoportok esetén. Sokan nyilatkoztak úgy is, hogy az online előadások, webináriumok alkalmával problémaforrást jelentett a használt program, felületet elégtelen ismerete. A válaszok alapján ez az oktatók 54,5, illetve a hallgatók 49,3 százalékára igaz. A meglehetősen magas érték különösen a hallgatók esetén meglepő, hiszen - mint azt korábban már bemutattuk ők nagyon jónak minősítették saját digitális felkészültségüket a távolléti oktatás elején. 


\section{A távolléti oktatás vége}

Az, hogy a távolléti oktatással kapcsolatban milyen jelzők jutottak először eszükbe válaszadóinknak, már előrevetíti azt is, hogyan viszonyulnak az átélt hónapokhoz a kérdezettek. Az ezt vizsgáló 10 fokú Likert-skálán bejelölt értékek valóban inkább a negatív irányba mutatnak, de az átlagból $(4,2)$ nem következik olyan erős ellenérzés, mint amilyet a nyitott kérdésre adott válaszok jeleztek (4. ábra).

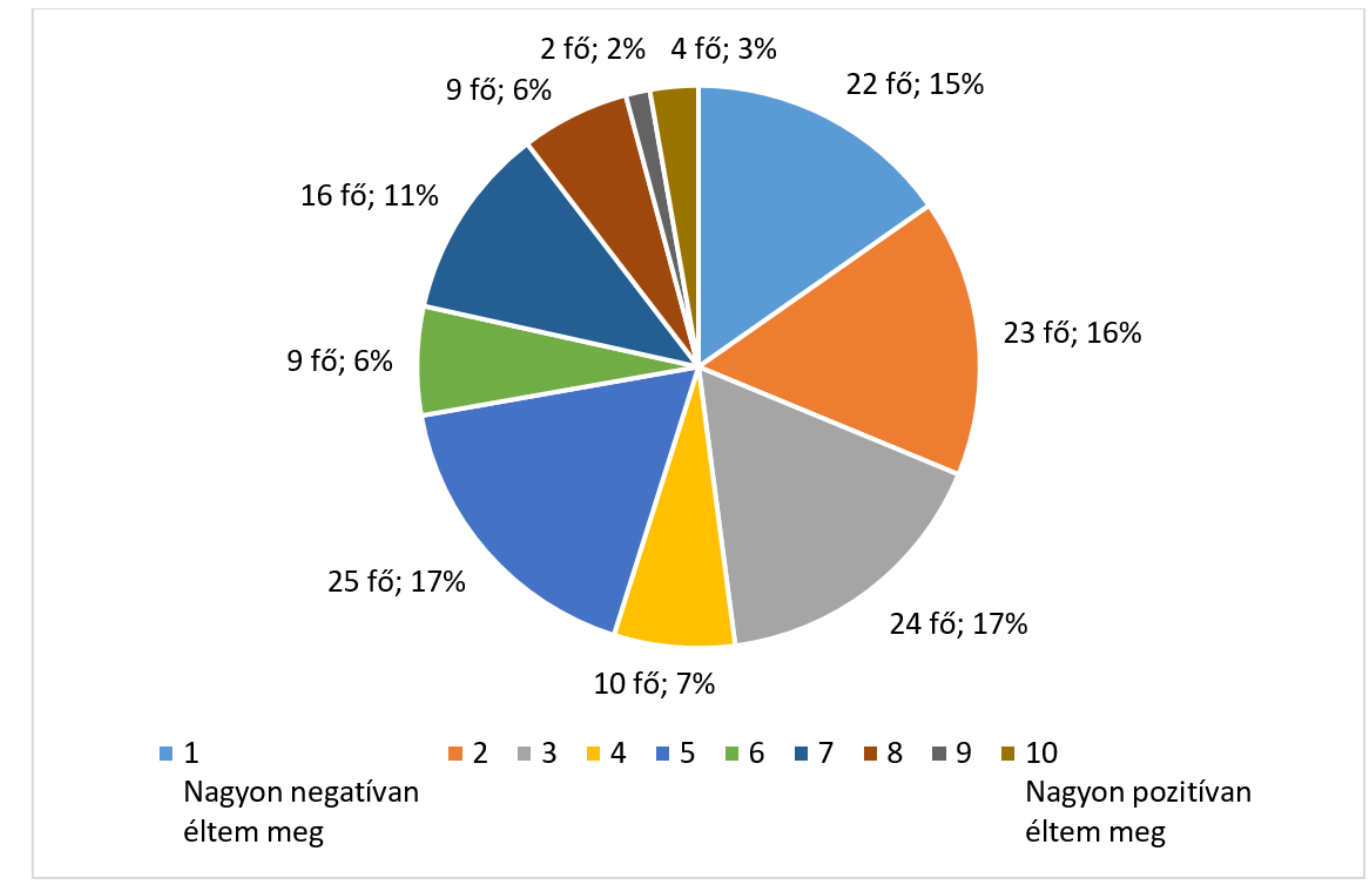

4. ábra: Hogyan viszonyulnak a hallgatók a távolléti oktatás időszakához? (n=144).

Összességében a válaszadók közel 3/4-e - igaz különböző mértékben -, de inkább negatívan viszonyul a távolléti oktatáshoz, ezen belül 22 fő (15\%) nagyon rosszul élte meg ezeket a hónapokat. Voltak azonban olyanok is (négyen), akikben ez az időszak nagyon pozitív érzeteket keltett. Erdekesség, hogy ők nem azok közül kerültek ki, akik a kérdőív elején feltett nyitott kérdésünkre három pozitív jelzőt írtak.

A hallgatók döntő többsége (több mint 4/5-e) örül, hogy befejeződött a távolléti oktatás (5. táblázat), és csak kevesen (19 fö) nyilatkoztak úgy, hogy megkedvelték ezt az oktatási formát (de még közöttük is vannak hatan, akik örülnek, hogy vége 
ennek az időszaknak). A zárt kérdésben megfogalmazott válaszalternatívák közül többet is meg lehetett jelölni, és szinte kivétel nélkül éltek is ezzel a lehetőséggel a hallgatók. Nagyon sokan (77,8\%) érezték magukat kimerültnek a válaszadáskor, ez nyilvánvalóan összefügg a jelentős leterheltség érzettel, ennek ellenére csak a hallgatók ötöde érezte úgy, hogy sokat fejlődött a távolléti oktatás ideje alatt. „Nem érzem, hogy új ismeretekkel gazdagodtam volna ezen időszak alatt, sokkal inkább kellett az előzetes tudásomra támaszkodnom” írta egyikük.

\begin{tabular}{lc|c}
\hline \multicolumn{1}{c}{ Állítások } & \multicolumn{2}{c}{ Az említések } \\
\cline { 2 - 3 } & Száma & Aránya \\
\hline Örülök, hogy vége! & 117 & $81,3 \%$ \\
Kimerülten & 112 & $77,8 \%$ \\
Frusztráltan & 62 & $43,1 \%$ \\
Sokat tanultam & 58 & $40,3 \%$ \\
Kényelmetlenül, a személytelenség miatt & 58 & $40,3 \%$ \\
Nem ismertem a távoktatást, nem is szerettem meg & 34 & $23,6 \%$ \\
Sokat fejlődtem & 31 & $21,5 \%$ \\
Megkedveltem ezt az oktatási formát & 19 & $13,2 \%$ \\
\hline
\end{tabular}

5. táblázat: Hogyan érzi magát a távolléti oktatás után? (n=144).

Ugyanakkor a hallgatók - egyébként is magasra értékelt - digitális felkészültségének átlagos szintje még tovább javult a távolléti oktatás ideje alatt (7,8-ról 8,1re), bár az előrelépés messze nem volt egyenletes (5. ábra). 


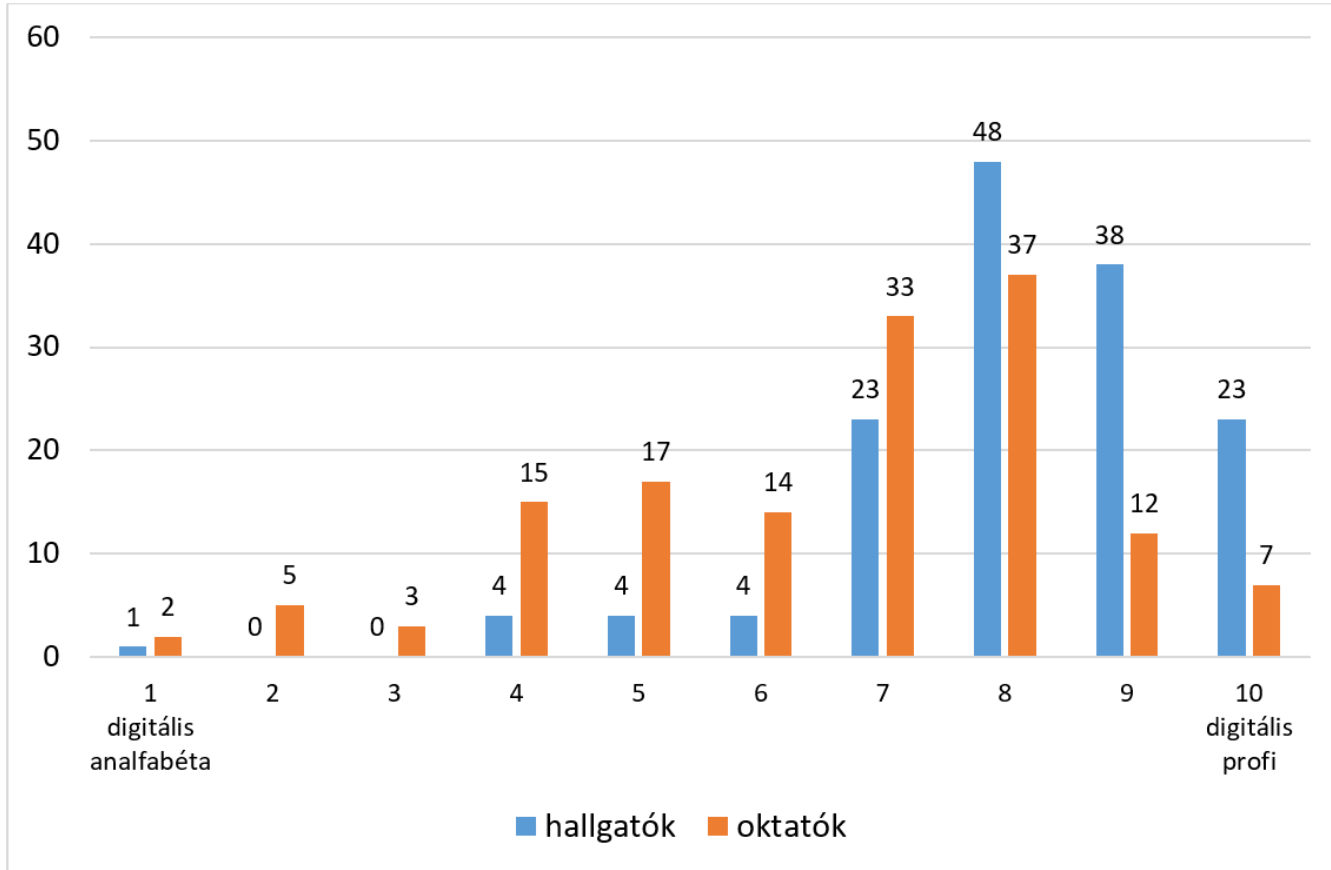

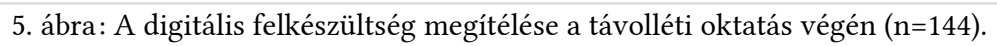

Előzetesen is várni lehetett valamennyi fejlődést, mivel nem csak hogy gyakran kellett alkalmazni a digitális technológiát, hanem számos új programmal, weboldallal is meg kellett ismerkedni, így a gyakorlottság, jártasság szintjének elvileg egyértelműen emelkednie kellett volna. Ezzel szemben minden bizonnyal pontosan a gyakori, szerteágazó és többcélú IKT használat miatt döbbentek rá többen is a hallgatók közül, hogy korábbi önbesorolásuk túlzó volt. Ennek következtében nem egyszer négy fokozattal is alacsonyabbra értékelték saját digitális felkészültségük szintjét a távolléti oktatás végén, mint annak kezdetekor. Az oktatók felkészültségének megítélése viszont jelentősen javult (a kezdeti 5,4-es átlagról 6,6-ra változott) és az ő esetükben még szélsőségesebb (pozitív irányú) a változás: több hallgató szerint tanárai hat fokot léptek elöre a tíz fokozatú skálán. Természetesen nem tekinthetjük valósnak a változások mértékét és irányát, ${ }^{6}$ hiszen szubjektív besorolás történt, ennek ellenére figyelemre méltó az eltérés a két csoport felkészültségi szintjének megítélése között. Különösen igaz ez, ha a megjelölt értékeket felhasználva csak a változás irányát vizsgáljuk (6. táblázat), de annak mértékét nem. Ebben az esetben az oktatók fejlỏdése még egyértelműbb, közel

${ }^{6}$ Ehhez valamilyen elfogadott mérőeszközt kellene használni (például DigCompEdu - lásd Horváth et al., 2020). 
másfélszer annyi hallgató szerint javult az oktatók digitális felkészültsége, mint ahányan saját magukról gondolták ezt.

\begin{tabular}{lccc}
\hline & Javult & Maradt & Romlott \\
\hline hallgatók & 64 & 56 & 24 \\
oktatók & 91 & 35 & 18 \\
\hline 6. táblázat: Hogyan változott a digitális felkészültség a távolléti oktatás \\
\end{tabular}

Végezetül azt kérdeztük meg a hallgatóktól, hogy ha választhatnának, hogy a következő tanévet hagyományos vagy távolléti formában teljesítsék, akkor melyiket választanák. A kérdőívet kitöltők többsége a hagyományos, jelenléti oktatást választaná (56\%). A válaszokhoz szöveges indoklást is kértünk, ezekben a legtöbben két olyan indokot neveztek meg, melyek a korábbi válaszokban is megjelentek, és nem a hagyományos forma pozitívumát, hanem a távolléti forma negatívumát emelték ki. Az egyik ilyen elem a távolléti oktatás személytelensége: „Hiányoztak a kontakt órák, illetve a személyes találkozások mind az oktatókkal, mind a csoporttársakkal. Hiányzott az egyetemi légkör, az egyetemi élet minden másodperce.” Akadt, aki számára nem is képzelhető el más oktatási forma: „Azért jelentkeztem nappali tagozatos képzésre, mert szükségem van a személyes magyarázatokra, a hallgatói életre.” A jelenlét nem csak szocializációs szempontból fontos, hanem más pozitív hatása is van: „sokkal nagyobb a motivációm, ha a körülöttem lévó emberek is tanulnak.” A jelenléti oktatás preferálásának másik kiemelkedő - korábban is említett - indoka a terheléshez kapcsolódik: „A távolléti oktatásnál sokkal többet vártak el, mint a hagyományos oktatásnál.” „A távoktatásnak köszönhetően minden tanár minimum dupla annyi anyagot adott, „mert nincs óra”,

Ezen túlmenően volt még két olyan indok a hagyományos oktatás mellett, mely többeknél megjelent. Az egyik a távolléti oktatás minőségét kifogásolta. „Őszintén, úgy érzem, nem feleltethetó meg egymásnak a hagyományos és a távoktatás. A távoktatásban nem a tananyag elsajátításán volt a hangsúly, hanem a jegyszerzés alapjául szolgáló beadandók elkészitésén.” Mások sokkal kritikusabban fogalmaztak: „A távoktatásból hiányzott az oktatás.”; „A tantárgyak nagy része valódi 
oktatás nélkül zajlik távoktatásban, a hallgató saját maga dolgozza fel az anyagokat."

Az indokok negyedik csoportja olyan elemhez kapcsolódik, mely a távoktatással kapcsolatban mindig is problémát jelentett, és mai napig nincs teljesen megnyugtató megoldása. Ez a terület az értékelés. „A távoktatás a legteljesebb mértékben igazságtalan. Azoknak kedvezett, akik a jelenléti oktatás alkalmával nem a legfényesebben teljesítettek, ellenben kellöen találékonyak. Ugrásszerü javulást értek el a középszerü tanulók.” Van, aki ennél konkrétabban fogalmaz: „számonkéréseknél legtöbb esetben lehet találni kibúvókat (,illegális segítséget”).”

Érdekes módon a hallgatók teljesítményének értékelése megjelent a távolléti oktatást preferálók (8\%) indokai között is: „Hiába van ott a puskázás lehetősége, azért ahhoz is kell egyfajta tudás a tananyagot illetően, hogy az adott választ hol keressük, tehát szerintem a puskázás ebben az esetben nem befolyásolta döntően az eredményeket." Az indokok között a jól ismert pozitívumokat (hely- és időfüggetlen tanulás) is megfogalmazták a hallgatók: „Vidéki hallgatóként hatalmas terhet vett le vállamról, hogy nem kellett minden reggel és délután is egy-egy órát utaznom." „Kényelmesebb itthonról tanulni, bár esetenként nagy a stressz a sok beadandó miatt, de így volt alkalmam magamnak beosztani az idómet, és így talán még jobban is teljesitettem, mint kontakt formában."

A kevert oktatási formát a hallgatók alig több mint harmada (36\%) részesítené előnyben. „Bizonyos helyzetekben szükség van távoktatásra. A tananyag bármikori visszatekinthetősége jelentősen segit a felkészülésben, mivel egy audiós ppt-t bármikor visszahallgathatok. Ez segít azoknak is, akik ütközés/munka miatt nem tudnak elóadásra járni. Minden egyéb szempontból azonban negatívnak tartom.” A legtöbben a kurzusok típusa alapján tennének különbséget az alkalmazott oktatási forma tekintetében: „A kollokviummal záródó tárgyakhoz tökéletesen elég lenne az Elearning felületre feltölteni az anyagot, mert aki akarja, úgy is meg tudja tanulni, illetve minden anyag megtalálható egy helyen. Gyakorlatoknál viszont fontosnak tartom a jelenlétet."

\footnotetext{
${ }^{7}$ Ezek a vélemények jelentősen egybecsengenek más kutatások eredményeivel (például Petillion \& McNeil, 2020; Serfőző et. al. 2020), sőt nem egyszer még a megfogalmazás is hasonló: „nincs igazán tanítás, csak feladatok és számonkérés" (Pap-Danka \& Lanszki, 2020, p. 55).
} 


\section{Következtetések, összegzés}

A Pew Research Center egy közel tíz évvel ezelőtti vizsgálatban több mint ezer szakértőt kérdezett meg az oktatás jövőjével kapcsolatban (Anderson et al., 2012). A kérdezettek hatvan százaléka azt tartotta a legvalószínűbbnek, hogy a felsőoktatás 2020-ra gyökeresen megváltozik. Úgy vélték, sokkal nagyobb szerepet kap majd az intézményekhez, tantermekhez kevéssé kapcsolódó online oktatás, és a tanulással kapcsolatos tevékenységeket alapvetően a diákok igényeihez igazítják majd. Mint tudjuk, ez a jövőkép nem valósult meg, annak ellenére, hogy a digitális technológia egyre jelentősebb szerepet tölt be az oktatásban. A tanítási, tanulási környezet csak kisebb mértékben változott, az online tér az e-learning és a MOOC (Massive Open Online Courses) képzések ellenére nem váltotta fel a hagyományos környezetet, hanem inkább csak kiegészítette azt.

A lassan, de egyre nagyobb mértékben megvalósuló digitális átállás a járványügyi helyzet miatt rendkívüli mértékben felgyorsult. A Semmelweis Egyetemen például néhány hét alatt közel kétszerannyi e-learning kurzust hoztak létre 2020 tavaszán, mint előtte majdnem 10 év alatt összesen (Keresztes, 2020). E figyelemre méltó érték jól érzékelteti a pandémia okozta változások egyik irányát, és jelzi azt is, hogy érdemes ezt az időszakot részletesebben megvizsgálni. Az általunk elvégzett kutatás során 2020 júniusában a Debreceni Egyetem tanárszakos hallgatóinak tapasztalatait gyüjtöttük össze a tavaszi (mint azóta már tudjuk az első) távolléti oktatás időszakával kapcsolatban.

A legtöbb válaszadóban a távolléti oktatás negatív érzeteket, tapasztalatokat generált: több mint 80 százalékuk örült, hogy befejeződött ez az időszak. A hallgatók számára a személyes találkozások elmaradása jelentette a legnagyobb negatívumot, a kérdezettek közel kétharmadának hiányoztak a társak és az oktatók. Kiemelkedő problémát jelentett még a jelentősen megnövekedett terheltség érzés is, annak ellenére, hogy csak oktatóik 32 százalékával kapcsolatban állították azt a válaszadók, hogy az online átállás miatt több követelményt írtak elő a tantárgy teljesítéséhez. Az ellentmondás feloldásában két tényező biztos szerepet játszik. Egyrészt az online órák több különböző platformon kerültek megtartásra, így minden hallgatónak legalább két-három, szélsőséges esetben viszont akár hat-hét felületet is meg kellett ismernie. Ez természetesen időigényes feladat, de szükséges feltétel a tanulás megkezdéséhez. Másrészt egy jelenléti órán passzívan jelen lenni, vagy ugyanannyi idő alatt egyénileg dolgozni, teljesen más érzeteket kelt, 
jelentősen eltér a két megoldás energiaszükséglete. Azaz, ha az oktató végső soron nem követelt több időráfordítást, csak más, nagyobb hallgatói aktivitást igénylő módszereket alkalmazott, akkor is érezhettek többen terhelésnövekedést. Mindezek következtében csak nagyon kevesen (8\%) szeretnék megtartani a távolléti oktatást, 56 százalék viszont inkább a hagyományos, jelenléti formát választaná. Ebből a szempontból eredményünk hasonló Johnson és társai 2000-ben lebonyolított vizsgálatának eredményéhez (Johnson et al., 2000), ami azért meglepő, mert a két vizsgálat között húsz év telt el. Ennyi idő alatt viszont nem csak a technológia és a különböző tanítást-tanulást segítő programok változtak meg jelentősen, hanem a hallgatók digitális írástudása is sokat fejlődött, és változott értékrendjük, attitűdjük is. Az online tanulás elutasításának háttérben éppen ezért minden bizonnyal eltérő motívumok játszanak szerepet, de ezek feltérképezése más megközelítésủ, mélyebb kutatást igényel.

Az elvégzett feltáró jellegű vizsgálatunk eredményeire reflektálva a tavasszal jelentős gondokat okozó legsúlyosabb problémák a 2020-21-es tanév őszi félévének távolléti oktatási időszakában már csak jóval kisebb mértékben jelentkeztek. Egyrészt csökkent a használt platformok köre, mivel jelentősen megemelkedett a Webex hozzáféréssel rendelkező oktatók száma. A szinkron órák megtartására alapvetően ezt a platformot javasolták a Multimédia Központ munkatársai, és a legtöbb egység vezetője is ezt szorgalmazta. Másrészt az elearning.unideb.hu (Moodle) felületen minden Neptunban meghirdetett tantárgyhoz létre kellett hozni egy online kurzust, mely az információk, a tananyagok és a kiegészítő anyagok elsődleges forrásaként szolgált a hallgatók számára. Ez a rendezettség eleve sokat segített. Mivel pedig már a félév elején fel kellett készülni az esetlegesen bekövetkező online átállásra, az oktatók sokkal gondosabban, átgondoltabban tervezhették meg a félév követelményeit, így a tavaszi ad hoc döntésekhez képest sokkal reálisabb, többlet terhelést nem okozó feladatok kerültek meghatározásra.

Bár kutatásunk a távolléti oktatás tapasztalatainak összegyüjtésére irányult, a hallgatói válaszokból kiolvasható (alapvetően negatív) érzetek, tapasztalatok közvetetten cáfolják azt a - Higgins és társai által mítosznak nevezett (Higgins et al., 2012) - vélekedést is, mely szerint az IKT-eszközök és a digitális megoldások oktatási alkalmazása mindig motiválja a tanulókat, és szívesebben, jobban tanulnak általuk. A távolléti oktatás alatt ugyanis adottak voltak ezek a megoldások, mindenki ezeket használta, a hallgatók többsége alapvetően mégis inkább a hagyományos oktatási formát választaná, ha ilyen döntési helyzetbe kerülne. Tehát az IKT 
alkalmazására is az igaz, ami minden más innovációra: a kezdeti időszakban az újdonság varázsa még motiváló, de az idő előrehaladtával ez a hatás exponenciálisan csökken, és a megoldás rövid időn belül teljesen megszokottá válik, elveszíti motiváló erejét. Különösen a tanárszakos hallgatóknak kell tisztában lenniük ezzel a hatással, hiba lenne ugyanis úgy tekinteniük az IKT-eszközökre, megoldásokra, mint olyan varázsszerekre, melyek mindig motiválóan hatnak a diákokra, és bármikor alkalmazhatók az óra színesítésére, a lankadó figyelem felkeltésére, de akár még fegyelmezésre is. Legalább ilyen súlyos hiba lenne azonban az is, ha szembesülve a digitális megoldások negatívumaival, rádöbbenve a varázsszer hatás hiányára, a leendő pedagógusok úgy döntenének, hogy nem áldoznak időt, energiát az IKT-eszközök, programok oktatásban történő alkalmazására.

\section{Irodalom}

Adams, M. J. D. \& Umbach, P. D. (2012). Nonresponse and online student evaluations of teaching: Understanding the influence of salience, fatigue, and academic environments. Research in Higher Education, 53(5), 576-591.

DOI: $10.1007 / \mathrm{s} 11$ 162-011-9240-5

Admiraal, W., Vugt, F., Kranenburg, F., Koster, B., Smit, B., Weijers, S. \& Lockhorst, D. (2017). Preparing pre-service teachers to integrate technology into K12 instruction: evaluation of a technology-infused approach, Technology, Pedagogy and Education, 26(1), 105-120. DOI: 10.1080/1475 939X.2016.1163283

Anderson, J., Boyles, J. L. \& Rainie, L. (2012). The Future of Higher Education. Pew Research Center, Internet \& Technology.

https://www.pewresearch.org/internet/2012/07/27/the-future-of-highereducation (2020. 07. 25.)

Aslan, A. \& Zhu, C. (2016). Influencing Factors and Integration of ICT into Teaching Practices of Pre-service and Starting Teachers. International fournal of Research in Education and Science, 2(2), 359-370. DOI: 10.21890/ijres.81048

Atkinson, S. P. (2020). How to engage and support students online. EDEN webinarium. https://sijen.com/wp-content/uploads/2020/04/EdenWebinar200 427.pdf (2020. 08. 15.)

Avery, R. J., Bryant, W. K., Mathios, A., Kang, H., \& Bell, D. (2006). Electronic course evaluations: Does an online delivery system influence student evaluations? The fournal of Economic Education, 37, 21-37.

DOI: 10.3200/JECE.37.1.21-37 
Bao, W. (2020). COVID -19 and online teaching in higher education: A case study of Peking University. Human Behavior and Emerging Technologies, 2(2), 113-115. DOI: $10.1002 /$ hbe2.191

Beullens, K., Loosveldt G., Vandenplas C. \& Stoop I. (2018). Response Rates in the European Social Survey: Increasing, Decreasing, or a Matter of Fieldwork Efforts? Survey Methods: Insights from the Field. DOI: 10.13094/SMIF-2018-00 003

Dringó-Horváth I. (2018). IKT a tanárképzésben: a magyarországi képzőhelyek tanárképzési moduljában oktatók IKT-mutatóinak mérése. Új Pedagógiai Szemle, 68(9-10), 13-41.

Dringó-Horváth, I. \& Gonda, Zs. (2018). Tanárjelöltek IKT-kompetenciájának jellemzői és fejlesztési lehetőségei. Képzés és Gyakorlat, 16(2), 21-48.

DOI: $10.17165 /$ TP.2018.2.2

Erdős, F. \& Koloszár, L. (2016). E-learning a hazai felsőoktatásban: gazdaságossági megközelítés. Gazdaság \& Társadalom, 8(2), 105-121.

DOI: $10.21637 / G T .2016 .2 .06$

Espino-Díaz, L., Fernandez-Caminero G., Hernandez-Lloret, C., Gonzalez-Gonzalez, H. \& Alvarez-Castillo, J. (2020). Analyzing the Impact of COVID-19 on Education Professionals. Toward a Paradigm Shift: ICT and Neuroeducation as a Binomial of Action. Sustainability, 12(14), 5646.

DOI: $10.3390 /$ su12 145646

Falus, I. (2001): Pedagógus mesterség - pedagógiai tudás. Iskolakultúra, 11(2), 21-28.

Fáyné, D. A., Hódi, Á. \& Kiss, R. (2016). IKT az óvodában: kihívások és lehetőségek. Magyar Pedagógia, 116(1), 91-117. DOI: 10.17670/MPed.2016.1.91

Ferri, F., Grifoni, P. \& Guzzo, T. (2020). Online Learning and Emergency Remote Teaching: Opportunities and Challenges in Emergency Situations. Societies, 10, 86. DOI: $10.3390 /$ soc 10040086

Főző, A. (2016). SAMR-létra. https://komposzt.wordpress.com/2016/11/22/samrletra/ (2020. 02. 22.)

Goldin, C. \& Katz, L. F. (2008). The Race Between Education and Technology. Belknap Press for Harvard University Press.

Gonzalez, T., de la Rubia, M., Hincz, K., Lopez, M. C., Subirats, L., Fort, S. \& Sacha, G. M. (2020). Influence of COVID-19 confinement in students' performance in higher education. DOI: 10.35542/osf.io/9zuac

Higgins, S., Xiao, Z. \& Katsipataki, M. (2012). The Impact of Digital Technology on Learning: A Summary for the Education Endowment Foundation. Full Report. Durhan University. https://bit.ly/3qO6Bhe (2020. 08. 28.) 
Holloway, D., Green, L. \& Livingstone, S. (2013). Zero to eight: young children and their internet use. EU Kids Online. LSE London. http://eprints.lse.ac.uk/52 630/ (2020. 09. 21.)

Horváth L., Misley H., Hülber L., Papp-Danka A., M. Pintér T. \& Dringó-Horváth I. (2020). Tanárképzők digitális kompetenciájának mérése - a DigCompEdu adaptálása a hazai felsőoktatási környezetre. Neveléstudomány: Oktatás - Kutatás - Innováció, 8(2), 5-25. DOI: 10.21549/NTNY.29.2020.2.1

Johnson, L., Becker, S. A., Cummins, M., Estrada, V., Freeman, A. \& Hall, C. (2016). NMC Horizon Report: 2016 Higher Education Edition, The New Media Consortium.

Johnson, S. D., Aragon, S. R., Shaik, N. \& Palma-Rivas, N. (2000). Comparative analysis of learner satisfaction and learning outcomes in online and face-toface learning environments. FI. of Interactive Learning Research, 11(1), 29-49.

Kasza G. (2020). Távolléti oktatás, hallgatói élmények. Egy kérdőíves kutatás eredményei. Tempus Közalapítvány.

https://tka.hu/docs/palyazatok/kasza_georgina_tka_uj_eloadas.pdf (2020. 02. 21.)

Keresztes, E. (2020). Fejlesztések az egyetemi e-learning rendszerben. https://semmelweis.hu/hirek/2020/06/17/folyamatosak-a-fejlesztesek-azegyetemi-e-learning-rendszerben/ (2020. 07. 25.)

Kismihók, G. (2011). Rugalmas Tanulás, Rugalmas Munkavégzés Az Ontológia Alapú Tartalommendzsment Lehetőségeinek Kiaknázása. Budapesti Corvinus Egyetem.

Kozma G. (Ed.) (2020). Fejezetek a COVID-19-es távoktatás digitális tapasztalataiból. Gerhardus Kiadó.

Lanszki, A. \& Faragó, B. (2020). Tanító- és tanárszakos hallgatók elképzelései IKTeszközök használatáról az oktatásban. Opus et Educatio, 7(1), 30-46.

DOI: 10.3311/ope.363

http://opuseteducatio.hu/index.php/opusHU/article/view/363/627 (2020. 08. 05.)

Lindemann, N. (2019): What's the average survey response rate?

https://surveyanyplace.com/average-survey-response-rate/ (2020. 02. 17.)

Lupton, D., Mewburn, I. \& Thomson, P. (Eds.) (2017). The Digital Academic. Critical Perspectives on Digital Technologies in Higher Education. Routledge https://www.routledge.com/The-Digital-Academic-Critical-Perspectives-onDigital-Technologies-in-Higher/Lupton-Mewburn-Thomson/p/book/ 9781138202580 (2020. 08. 28.)

Magai, Á. \& Simonics, I. (2008). The Development of eServices in an Enlarged EU: eLearning in Hungary. Seville: European Commission Joint Research Centre In- 
Pedagógusképzés • 19(47), 2020/1-2.

stitute for Prospective Technological Studies.

https://publications.jrc.ec.europa.eu/repository/bitstream/JRC42 868/

jrc42 868.pdf (2020. 07. 27.)

Marinoni, G., van't Land, H. \& Jensen, T. (2020). The impact of COVID-19 on higher education around the world. IAU Global Survey Report.

https://www.iauaiu.net/IMG/pdf/iau_covid19_and_he_survey_report_final_ma y_2020.pdf (2021.02.21.)

Martin, T. \& Sherin, B. (2013). Learning Analytics and Computational Techniques for Detecting and Evaluating Patterns in Learning: An Introduction to the Special Issue. Fournal of the Learning Sciences, 22(4), 511-520.

DOI: $10.1080 / 10508406.2013 .840466$

McKenney, S. \& Voogt, J. (2012). Teacher design of technology for emergent literacy: An explorative feasibility study. Australasian fournal of Early Childhood, 37(1), 4-12. DOI: 10.1177/183693911203700102

Mol, C. V. (2017). Improving web survey efficiency: the impact of an extra reminder and reminder content on web survey response. International fournal of Social Research Methodology, 20(4), 317-327.

DOI: 10.1080/13645 579.2016.1185255

Molnár, Gy., Turcsányi-Szabó, M. \& Kárpáti, A (2020): Digitális forradalom az oktatásban - perspektívák és dilemmák. Magyar Tudomány, 181(1), 56-67.

DOI: 10.1556/2065.181.2020.1.6

Molnár, Gy., Turcsányi-Szabó, M. \& Kárpáti, A. (2019). Az interaktív tanulási környezetektől a módszertani megújuláson át a kreatív önkifejezésig. Új Pedagógiai Szemle, 69(11-12), 53-70.

Nichols, M. (2020). Transforming Universities with Digital Distance Education. The Future of Formal Learning. Routledge. DOI: 10.4324/9780 429463952

Nulty, D. D. (2008). The adequacy of response rates to online and paper surveys: what can be done? Assessment \& Evaluation in Higher Education, 33(3), 301-314. DOI: 10.1080/02602930701293231

Ottenbreit-Leftwich, A., Liao, J. Y., Sadik, O. \& Ertmer, P. (2018). Evolution of Teachers' Technology Integration Knowledge, Beliefs, and Practices: How Can We Support Beginning Teachers Use of Technology? Journal of Research on Technology in Education, 50(4), 282-304. DOI: 10.1080/15391523.2018.1487350

Papp-Danka, A. \& Lanszki, A. (2020). A digitális munkarend tapasztalatai a Magyar Táncművészeti Egyetemen. Tánc és Nevelés, 1(1), 37-58.

DOI: $10.46819 / \mathrm{TN} \cdot 1.1 .37-58$

Petillion, R. J. \& McNeil, W. S. (2020). Student Experiences of Emergency Remote Teaching: Impacts of Instructor Practice on Student Learning, Engagement, 
and Well-Being. Chemical Education, 97(9), 2486-2493.

DOI: 10.1021/acs.jchemed.0c00 733

Picciano, A. G. (2019). Online Education: Foundations, Planning, and Pedagogy. Taylor \& Francis.

Rahiem, M. D. H. (2020). The Emergency Remote Learning Experience of University Students in Indonesia amidst the COVID-19 Crisis. International fournal of Learning, Teaching and Educational Research, 19(6), 1-26.

DOI: $10.26803 /$ ijlter.19.6.1

Sax, L. J., Gilmartin, S. K. \& Bryant, A. N. (2003). Assessing response rates and nonresponse bias in web and paper surveys. Research in Higher Education, 44, 409-432. DOI: 10.1023/A:1 024232915870

Serfőző M., Golyán Sz., F. Lassú Zs., Svraka B. \& Aggné P. V. (2020). Digitalizáció és online tanulás a pedagógusképzésben - hallgatói visszajelzések a távolléti oktatásról. Civil szemle, 17(Klnsz.), 105-116.

Srivastava, S., Jacob, J., Charles, A. S. Daniel, P., Mathew, J. K., Shanthi, P., Devamani, K., Mahasampath, G. \& Rabi. S. (2021). Emergency remote learning in anatomy during the COVID-19 pandemic: A study evaluating academic factors contributing to anxiety among first year medical students. Medical fournal Armed Forces India, 77(6), S90-S98. DOI: 10.1016/j.mjafi.2020.12.012

Starkey, L. (2010). Supporting the digitally able beginning teacher. Teaching and Teacher Education, 26(7), 1429-1438. DOI: 10.1016/j.tate.2010.05.002

Tondeur, J., Roblin, N. P., van Braak, J., Voogt, J. \& Prestridge, S. (2016). Preparing beginning teachers for technology integration in education: Ready for takeoff? Technology Pedagogy and Education, 26(2),157-177.

DOI: 10.1080/1 475 939X.2016.1193556

Tóth, K. \& Molnár, Gy. (2009). Tanár szakos hallgatók IKT használati szokásai és preferenciái. In Molnár, Gy. \& Kinyó, L. (Eds.), VII. Pedagógiai Értékelési Konferencia (p. 34). Szegedi Tudományegyetem.

Turcsányi-Szabó, M. (2011). Fenntartható innováció a tanárképzésben - az elmélettől a gyakorlatig. Oktatás-Informatika, 3-4, 32-44.

http://www.eltereader.hu/media/2013/05/Okt_Inf_2011_3_4_opt.pdf (2020. 07. 13.)

UNESCO (2020). COVID-19 Impact on Education. https://en.unesco.org/covid19 (2020. 02. 21.)

Veresné Balajti I. (2010). Egyetemi hallgatók egészségi állapota és egészségmagatartása. $\mathrm{PhD}$ értekezés. Debreceni Egyetem Egészségtudományi Doktori Iskola. 
World Economic Forum (2016). The future of jobs. Employment, skills and workforce strategy for the fourth industrial revolution.

http://www3.weforum.org/docs/WEF_Future_of_Jobs.pdf (2020.06.11.)

\section{Education during COVID-19. Teacher trainees' opinion on distance education}

The appearance of the Coronavirus, fundamentally changed the process of permanent digitisation. Employees of public education had to retool to distant teaching in a very short time, but institutions of higher education, similarly, had a mere couple of days to develop new content and methods.

In our study, with the help of an online questionnaire consisting of both openended and closed-ended questions, we accumulated the opinions and experiences of education majors of the University of Debrecen upon their completion of the period of distant teaching. 144 students responded to our questions. The study shows, through a more detailed presentation of findings, how successful the switch was according to the students, which were the most characteristic problems of this new form of education and which are those elements that can improve traditional attendance learning.

Keywords: ICT, COVID-19, teacher trainees, experience, distance education 